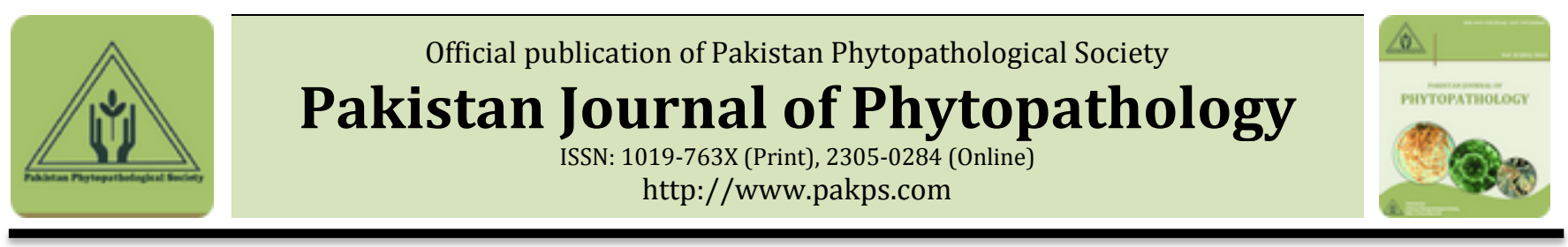

\title{
EFFECTIVENESS OF DIFFERENT FUNGICIDES AGAINST PREDOMINANT AND VIRULENT FUNGUS FUSARIUM NIVALE THE CAUSE OF MANGO MALFORMATION DISEASE
}

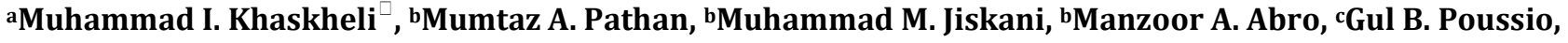 \\ dAllah J. Khaskheli \\ ${ }^{a}$ Department of Plant Protection, Sindh Agriculture University, Tando Jam-70060, Pakistan. \\ ${ }^{b}$ Department of Plant Pathology, Sindh Agriculture University, Tando Jam-70060, Pakistan. \\ cPlant Pathology Section, Agriculture Research Institute, Tando Jam-70060, Pakistan. \\ ${ }^{d}$ Department of Biotechnology, Sindh Agriculture University, Tando Jam-70060, Pakistan.
}

\section{A B S T R A C T}

Fusarium nivale (Fr.) Ces. a recently reported fungus of mango malformation disease (MMD)is a predominant and virulent fungus in mango orchards of Sindh, Pakistan. In the current study, in vitro and in vivo attempts were made with commercial fungicides to reduce the severity of $F$. nivale. Mycelial growth of $F$. nivale was significantly inhibited at low and high doses of Thiophanate methyl and Fosetyl- Aluminium. Metalaxyl+Mancozeb and Mancozeb also reduced growth of fungus at their high doses $(6.830$ and $11.900 \mathrm{~mm})$, respectively, as compared to Copper oxychloride $(18.083 \mathrm{~mm})$ and control $(40.750 \mathrm{~mm})$. Thiophanate methyl and Fosetyl- Aluminium significantly reduced infection in Desi, Almas and Dusheri to 16.60 and $19.00 \%$; 17.60 and $19.80 \%$; and 20.60 and $22.00 \%$ after first spray, with decreased percent of malformation 72.33 and $68.33 \%$; 71.11 and $67.54 \%$; and 67.81 and $65.62 \%$ and over untreated control. The second spray of Thiophanate methyl and Fosetyl- Aluminium fungicides completely inhibited infection of F. nivale, and $100.0 \%$ reduction in malformation disease in Desi, Almas, and Dusheri as compared to Metalaxyl+Mancozeb (78.73, 73.84, 72.64\%) and Mancozeb (73.65, 73.69, 69.41\%), Copper oxychloride and in control. The application of Thiophanate methyl and Fosetyl- Aluminium would be useful in integrated management of MMD.

Keywords: Fusarium nivale; Mango Malformation; Intensity; Fungicides

\section{INTRODUCTION}

Mango (Mangifera indica L.) is one of the oldest and the most important fruit of the tropical world including Indo Pak subcontinent where it is known to be cultivated from ages. Pakistani mangoes have attained a good reputation due to their excellent flavour, delicious taste and nutritive values (Muhammad et al., 2002). Mango is the second important fruit crop of the country to earn foreign exchange by exporting to Middle East and Europe (Tahir et al., 2003).

The average yield, however, is not appreciable which is due to the negligence of growers and attacks of

* Corresponding Author:

Email: mikhaskheli@sau.edu.pk

(C) 2017 Pak. J. Phytopathol. All rights reserved. several insect pests, abiotic factors and diseases, about 81 diseases have been recorded on mango (Pernezny and Simone, 2000). Mango malformation disease (MMD) is a serious threat to this crop and is of increasing significance because of great demand of mango in the international market and expansion of mango production worldwide for export (Ahmed et al., 2002). Mango malformation is of two types, vegetative and floral, floral malformation is more prevalent in bearing mango tress, however, vegetative malformation mostly appears on seedlings (Khaskheli et al., 2008a). MMD causes shortened inflorescence, sterility and aborted hermaphrodite flowers and the male flowers increase in number and size (Kumar et al.,1993; Akhtar et al., 1999; Ahmed et al., 2002; Iqbal et al., 2006). MMD was first reported in India in 1891 
(Ploetz, 2001). It is found elsewhere in Asia [Israel, Malaysia, and Pakistan (Ploetz, 2001)], Africa [Egypt, South Africa, Sudan, Swaziland, and Uganda (Ploetz et al., 2002)] and Americas [Brazil, El Salvador, Mexico, Nicaragua, the United States and Venezuela (Noriega et al., 1999 and Britz et al., 2002)]. In Pakistan, Khaskheli et al., (2008b) confirmed with pathogenicity Fusarium nivale (Fr.) Ces., as first record in Pakistan and also the first report of its association with mango malformation disease in Sindh, Pakistan. In another study, Iqbal et al., (2006) isolated four fungi viz. F. mangiferae, F. pallidoroseum, F. oxysporum and Alternaria alternata from malformed mango parts. Akhtar et al., (1999) verified the association $F$. moniliforme and $G$. fujikuroi with the disease.

Several attempts were made to manage the MMD, however, due to differences in the reported species some time difficult to control the extent of MMD. Some research lines indicate that broad spectrum systemic fungicides are beneficial for the control of the disease (Lonsdale and Kotze, 1993). Kumar et al., (1995) found that mangiferin, the metabolites of mango induced changes in isolates of Fusarium moniliforme (Gibberella fujikuroi). Iqbal et al., (2011) conducted study on management of mango malformation through physical alteration and chemical spray, in their study the treatment with clipping at $45 \mathrm{~cm}$ distance followed by spray of benomyl results $70.37 \%$ decrease over previous year's count.

For the last many years researchers have been involved to study various aspects of MMD but so far its management no systematic work is reported to have been done in Sindh province of Pakistan. The present studies were therefore carried out to investigate management with available fungicides to get the solution of MMD in Sindh province.

\section{MATERIALS AND METHODS}

Fungal culture: The fresh culture of Fusarium nivale (Fr.) Ces. obtained from the Department of Plant Pathology, Sindh Agriculture University, Tando Jam, Pakistan was used in the current experiment. Furthermore, Fusarium nivale (Fr.) Ces. was confirmed and proved with pathogenicity test as first recorded fungi from mango malformation disease in Sindh, Pakistan in our previous experiments.
In vitro fungicide test: Five different fungicide were tested in vitro; Fosetyl- Aluminium, Copper oxycloride, Mancozeb, Metalaxyl+Mancozeb, and Thiophanate methyl. The basal medium was amended with three different doses of each fungicide. The doses of each fungicide were prepared according to their active ingredient (Table 1). Petri dishes containing amended PDA medium were inoculated with $3 \mathrm{~mm}$ disk removed with sterilized cork-borer from the growing margin of a 7 days old culture of Fusarium nivale. Petri dishes containing PDA medium without fungicides were used as control. All the plates were incubated at $25 \pm 1^{\circ} \mathrm{C}$ for about 10 days. Mycelial growth of the fungus was recorded in $\mathrm{mm}$ after 24 hours of inoculation and after 10 days of growth. The experiment was conducted in completely randomized design (CRD) with four replications for each treatment.

In vivo fungicide test: Effect of different fungicides on the disease development on inoculated mango nursery was carried to confirm the efficacy. 10 healthy seedlings of each 3 susceptible varieties i.e. Almas, Dusheri, and Desi were inoculated by injecting $3 \mathrm{ml}$ spore suspension $\left(10^{7}\right.$ conidiaml $\left.{ }^{-1}\right)$ of the fungus Fusarium nivale just below growing tip of the nursery. After 30 days of inoculation, nurseries were sprayed two times with five different fungicides at 10 days interval. Mango nurseries sprayed with distilled sterile water were treated as control. The experiment was arranged in randomized complete block design (RCBD) with three replications. The fungicides at their different doses used are mentioned in Table 1 . To record the data, samples were collected 72 hours after each spray to find the reduction in extent of infection. The infection percentage was determined using 0-5 scale described by Towsend and Henberger (1973): where; 0 =No infection (0\%), 1= Slightly infection (20\%), $2=$ Moderate infection (40\%), 3=Slightly severe infection (60\%), 4=Severe infection $(80 \%)$ and $5=$ Dead inflorescence (100\%).

Statistical analysis: Data were analysed according to standard procedures for analysis of variance, ANOVA (linear model), and separation of means (least significant difference, LSD) of all parameters was determined using Statistix 8.1(Analytical Software 2005). All differences described in the text were considered significant at the $5 \%$ level of probability. 
Pak. J. Phytopathol., Vol. 29 (01) 2017. 137-143

Table 1. List of different fungicides used for the management of Fusarium nivale

\begin{tabular}{|c|c|}
\hline $\begin{array}{l}\text { Dose use } \\
\text { (under L } \\
\text { in } 100^{-1} \mathrm{r}\end{array}$ & $\begin{array}{l}\text { Dose used } \\
\text { (under Field) } \\
\text { in } 100^{-1} \mathrm{ml} \text { Water }\end{array}$ \\
\hline Fosetyl- Aluminium $80 \mathrm{WP}$ & $350 \mathrm{mg}$ per \\
\hline $\begin{array}{l}1.200 \mathrm{~m} \\
2.250 \mathrm{~m} \\
3.300 \mathrm{~m}\end{array}$ & $300 \mathrm{mg}$ \\
\hline $\begin{array}{l}1.250 \mathrm{~m} \\
2.300 \mathrm{~m} \\
3.350 \mathrm{~m}\end{array}$ & $350 \mathrm{mg}$ \\
\hline Metalaxyl+Mancozeb72 WP & $300 \mathrm{mg}$ \\
\hline Thiophanate methyl $70 \mathrm{WP}$ & $200 \mathrm{mg}$ \\
\hline $\begin{array}{l}\text { RESULTS } \\
\text { In vitro efficacy of different fungicides against } \\
\text { Fusarium nivale: The efficacy of five different } \\
\text { fungicides (Thiophanate methyl, Fosetyl- Aluminium, } \\
\text { Metalaxyl+Mancozeb, Copper oxychloride and } \\
\text { Mancozeb) used against F. nivale at their different } \\
\text { doses showed significant difference }(P<0.05 \text { )in the } \\
\text { reduction of mycelialcolony growth. However, } \\
\text { Thiophanate methyl and Fosetyl- Aluminium at their } \\
\text { lower and higher doses completely inhibited the } \\
\text { colony growth of the fungus even after } 10 \text { day's } \\
\text { growth (Figure } 1 \text { ). Metalaxyl+Mancozeb at its lower } \\
\text { dose also reduced mycelium growth ( } 8.880 \text { mm) of } \\
\text { fungus. However, there was no significant difference } \\
\text { in colony growth of the fungus at medium and high } \\
\text { doses of Metalaxyl+Mancozeb (Figure 1), } \\
\text { respectively (Table 2). Mancozeb was found less } \\
\text { effective against the fungus as compared to } \\
\text { Metalaxyl+Mancozeb (Figure 1). There was no } \\
\text { significant difference in the colony growth of the } \\
\text { fungus recorded at low and medium dose of } \\
\text { Mancozeb (Table 2). Copper oxychloride was the } \\
\text { least effective at its respective doses, in retarding the } \\
\text { colony growth of the fungus (Figure } 1 \text { ). All the } \\
\text { fungicides at their respective doses significantly } \\
\text { retarded the growth of fungus as compared to } \\
\text { control (40.750 mm) (Table 2). }\end{array}$ & $\begin{array}{l}\text { Efficacy different fungicides on disease } \\
\text { development: The efficacy of five different } \\
\text { fungicides were tested on } 10 \text { healthy seedlings of } \\
\text { three selective susceptible mango varieties } \\
\text { inoculated with F. nivale showed significant } \\
\text { difference in the diseases development. The infection } \\
\text { percentage of tested seedlings after first and second } \\
\text { sprays is revealed in Table } 3 \text { that depicted significant } \\
\text { variation in the development of disease caused by F. } \\
\text { nivale. } \\
\text { Effect on Desi variety: The data recorded after the } \\
\text { first spray for Desi variety showed that Thiophanate } \\
\text { methyl reduced the infection of } F \text {. nivale to } 10.0 \% \text { i.e. } \\
72.33 \% \text { percent decreased in malformation intensity } \\
\text { over untreated control (Table 3). Fosetyl- } \\
\text { Aluminium, Metalaxyl+Mancozeb and Mancozeb also } \\
\text { reduced the infections as compared to Copper } \\
\text { oxychloride i.e. } 19.0,20.60,23.80 \text { and } 33.00 \% \text { with } \\
\text { reduction in disease intensity is } 68.33,65.66,60.33 \\
\text { and } 45.00 \% \text { over untreated control (Table } 3 \text { ). The } \\
\text { second spray of Thiophanate methyl and Fosetyl- } \\
\text { Aluminium completely reduced the infection of } \\
\text { fungus, with reduction in disease intensity by } \\
100.0 \% \text { as compared to Metalaxyl+Mancozeb, } \\
\text { Mancozeb, and Copper oxychloride with reduction } \\
\text { disease intensity by } 78.73 \text {, } 73.65 \text { and } 68.88 \% \text { over } \\
\text { control (Table } 3 \text { ). }\end{array}$ \\
\hline
\end{tabular}




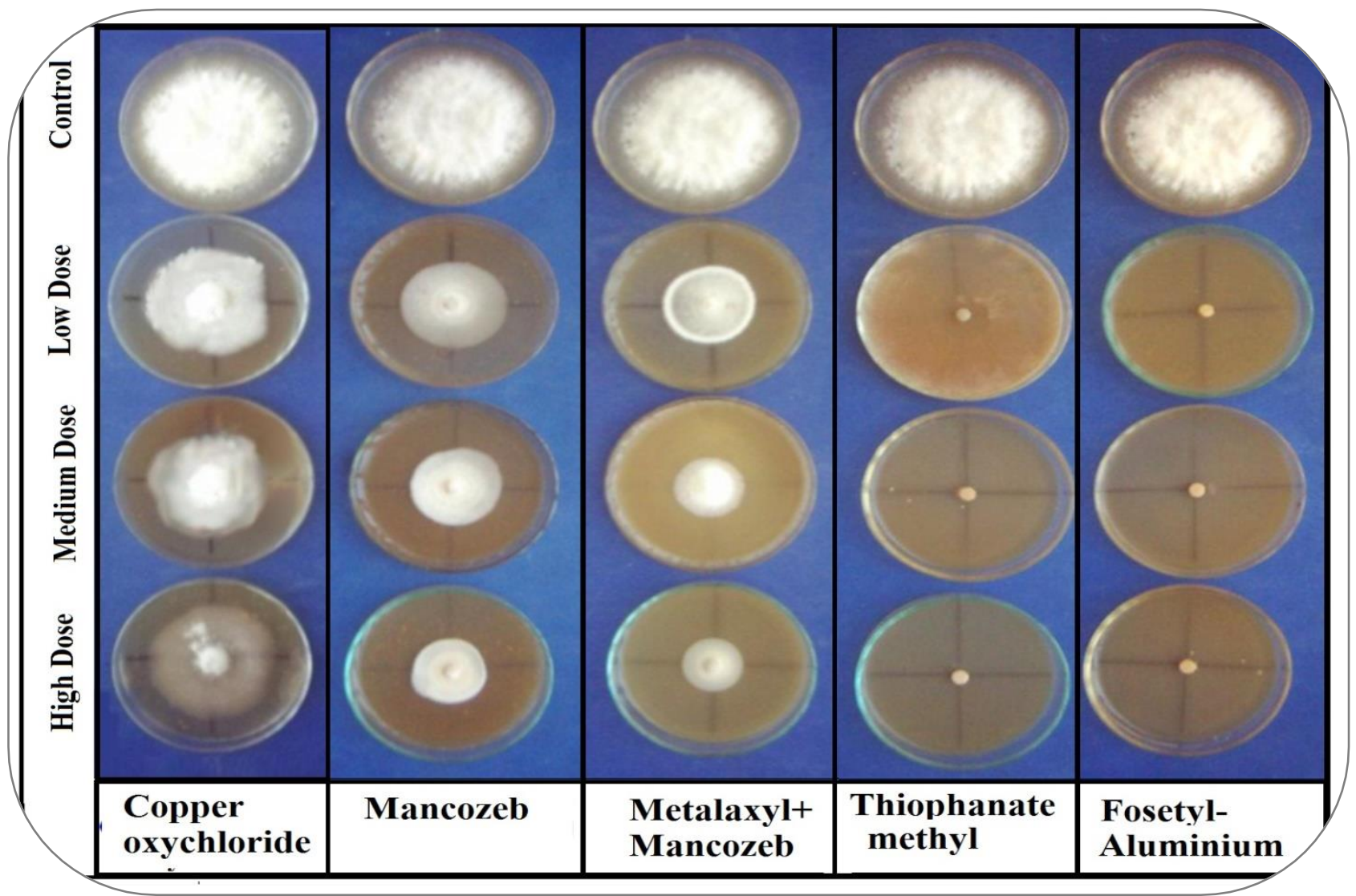

Figure 1. In vitro efficacy of different fungicide against mycelial growth of Fusarium nivale

Table 2. Effect of different fungicides on mycelial growth of Fusarium nivale

\begin{tabular}{llll}
\hline Fungicide & \multicolumn{2}{l}{ Dose $(\mathrm{mg}) /$} & Radial colony growth $(\mathrm{mm})$ \\
\hline Thiophanate methyl70 WP & $100 \mathrm{ml}$. medium & $3.416 \mathrm{i}$ \\
& 2 & 100.0 & $3.375 \mathrm{i}$ \\
& 3 & 200.0 & $3.250 \mathrm{i}$ \\
\hline Fosetyl- Aluminium 80 WP & 1 & 250.0 & $4.916 \mathrm{~h}$ \\
& 2 & 300.0 & $4.750 \mathrm{~h}$ \\
& 3 & 350.0 & $4.583 \mathrm{~h}$ \\
\hline Metalaxyl+Mancozeb72 WP & 1 & 200.0 & $8.880 \mathrm{f}$ \\
& 2 & 250.0 & $7.230 \mathrm{~g}$ \\
& 3 & 300.0 & $6.830 \mathrm{~g}$ \\
\hline Mancozeb45 WP & 1 & 250.0 & $13.338 \mathrm{~d}$ \\
& 2 & 300.0 & $13.090 \mathrm{~d}$ \\
& 3 & 350.0 & $11.900 \mathrm{e}$ \\
\hline Copper oxychloride 50 WP & 1 & 200.0 & $21.833 \mathrm{~b}$ \\
& 2 & 250.0 & $21.500 \mathrm{~b}$ \\
\hline Control & 3 & 300.0 & $18.083 \mathrm{c}$ \\
\hline LSD (P = 0.05) & & & $40.750 \mathrm{a}$ \\
\hline
\end{tabular}


Table 3. Effect of different fungicide on infection (percent) of on mango seedlings of Desi variety inoculated with Fusarium nivale

\begin{tabular}{llllll}
\hline Fungicide & $\begin{array}{l}\text { Dose }(\mathrm{mg}) / \\
100 \mathrm{ml}\end{array}$ & \multicolumn{3}{c}{ Infection (\%) after } \\
\cline { 3 - 6 } & distilled water & First spray & $\begin{array}{l}\text { *Reduction } \\
(\%) \text { over control }\end{array}$ & Second spray & $\begin{array}{l}\text { Reduction } \\
\text { (\%) over control }\end{array}$ \\
\hline Thiophanate methyl70 WP & 200.0 & $16.60 \mathrm{e}$ & 72.33 & $0.00 \mathrm{e}$ & 100.0 \\
Fosetyl- Aluminium 80 WP & 350.0 & $19.00 \mathrm{~d}$ & 68.33 & $0.00 \mathrm{e}$ & 100.0 \\
Metalaxyl+Mancozeb72 WP & 300.0 & $20.60 \mathrm{~d}$ & 65.66 & $13.40 \mathrm{~d}$ & 78.73 \\
Mancozeb45 WP & 350.0 & $23.80 \mathrm{c}$ & 60.33 & $16.60 \mathrm{c}$ & 73.65 \\
Copper oxychloride 50 WP & 300.0 & $33.00 \mathrm{~b}$ & 45.00 & $19.60 \mathrm{~b}$ & 68.88 \\
Control & $(-)$ & $60.00 \mathrm{a}$ & - & $63.00 \mathrm{a}$ & - \\
LSD (P= 0.05) & & 2.064 & - & 2.797 & - \\
\hline
\end{tabular}

*Reduction (\%) = Untreated seedlings - Treated seedlings / Untreated seedlings $\mathrm{x} 100$

Note. Figures followed by the same letter within a column were not significantly different according to the LSD (least significant difference) test at $\mathrm{P}<0.05$

Effect on Almas variety: Thiophanate methyl and Fosetyl-Aluminium after first spray also reduced the infection of fungus by 17.60 and $19.80 \%$ i.e. 71.11 and 67.54 percent decrease in malformation incidence over untreated control (61.0\%), respectively on Almas variety (Table 4). Metalaxyl+Mancozeb, Mancozeb and Copper oxychloride also significantly reduced the infection of the fungus, with reduction percent in malformation intensity by $65.57,60.98$ and $44.26 \%$ respectively (Table 4). The data of second spray revealed that Thiophanate methyl and Fosetyl-Aluminium reduced the infection of fungus by $100.00 \%$. Metalaxyl+Mancozeb, Mancozeb, and Copper oxychloride were also found effective in reducing infection of the fungus and percent decrease in disease intensity by 73.84, 73.69 and $69.53 \%$ over untreated control of Almas variety, respectively (Table 4).

Table 4. Effect of different fungicide on infection (percent) of on mango seedlings of Almas variety inoculated with Fusarium nivale

\begin{tabular}{|c|c|c|c|c|c|}
\hline \multirow[t]{2}{*}{ Fungicide } & \multirow{2}{*}{$\begin{array}{l}\text { Dose }(\mathrm{mg}) / \\
100 \mathrm{ml} \\
\text { distilled water }\end{array}$} & \multicolumn{4}{|c|}{ Infection (\%) after } \\
\hline & & First spray & $\begin{array}{l}{ }^{*} \text { Reduction } \\
\text { (\%) over } \\
\text { Control }\end{array}$ & Second spray & $\begin{array}{l}\text { Reduction } \\
\text { (\%) over } \\
\text { control }\end{array}$ \\
\hline Thiophanate methyl70 WP & 200.0 & $17.60 \mathrm{e}$ & 71.11 & $00.0 \mathrm{~d}$ & 100.0 \\
\hline Fosetyl- Aluminium 80 WP & 350.0 & $19.80 \mathrm{~d}$ & 67.54 & $0.00 \mathrm{~d}$ & 100.0 \\
\hline Metalaxyl+Mancozeb72 WP & 300.0 & $21.00 \mathrm{~d}$ & 65.57 & $17.00 \mathrm{c}$ & 73.84 \\
\hline Mancozeb45 WP & 350.0 & $23.80 \mathrm{c}$ & 60.98 & $17.10 \mathrm{c}$ & 73.69 \\
\hline Copper oxychloride 50 WP & 300.0 & $34.00 \mathrm{~b}$ & 44.26 & $19.80 \mathrm{~b}$ & 69.53 \\
\hline Control & $(-)$ & $61.00 \mathrm{a}$ & - & $65.00 \mathrm{a}$ & - \\
\hline $\operatorname{LSD}(\mathrm{P}=0.05)$ & & 2.160 & - & 2.700 & - \\
\hline
\end{tabular}

*Reduction (\%) = Untreated seedlings - Treated seedlings / Untreated seedlings x 100

Note. Figures followed by the same letter within a column were not significantly different according to the LSD (least significant difference) test at $\mathrm{P}<0.05$

Effect on Dusheri variety: The frequency of fungal infection on Dusheri variety was also significantly decreased by Thiophanate methyl and FosetylAluminium after first spray, 20.60 and 22.00\%, respectively, with percent reduction in intensity of malformation by 67.81 and $65.62 \%$, respectively (Table 5). Metalaxyl+Mancozeb, Mancozeb, and Copper oxychloride were also proved to be effective in reducing infection of $F$. nivale with percent decrease in disease intensity by $60.93,59.37$ and $42.18 \%$ (Table 5). In the second spray with Thiophanate methyl and Fosetyl- Aluminium, infection of the fungus was completely reduced, decreasing incidence of the disease by $100.0 \%$ as compared to Metalaxyl+Mancozeb (18.60\%), Mancozeb (20.80\%) and Copper oxychloride (21.00\%), with percent decrease in malformation intensity by $72.64,69.41$, and $69.11 \%$ over untreated control of Dusheri variety, respectively (Table 5). . 
Table 5. Effect of different fungicide on infection (percent) of on mango seedlings of Dusheri variety inoculated with Fusarium nivale

\begin{tabular}{|c|c|c|c|c|c|}
\hline \multirow[t]{2}{*}{ Fungicide } & \multirow{2}{*}{$\begin{array}{l}\text { Dose (mg)/ } \\
100 \mathrm{ml} \\
\text { distilled water }\end{array}$} & \multicolumn{4}{|c|}{ Infection (\%) after } \\
\hline & & First spray & $\begin{array}{l}\text { *Reduction } \\
\text { (\%) over } \\
\text { Control }\end{array}$ & Second spray & $\begin{array}{l}\text { Reduction } \\
\text { (\%) over } \\
\text { control }\end{array}$ \\
\hline Thiophanate methyl70 WP & 200.0 & $20.60 \mathrm{~d}$ & 67.81 & $00.0 \mathrm{~d}$ & 100.0 \\
\hline Fosetyl- Aluminium $80 \mathrm{WP}$ & 350.0 & $22.00 \mathrm{~cd}$ & 65.62 & $00.0 \mathrm{~d}$ & 100.0 \\
\hline Metalaxyl+Mancozeb72 WP & 300.0 & $25.00 \mathrm{~cd}$ & 60.93 & $18.60 \mathrm{c}$ & 72.64 \\
\hline Mancozeb45 WP & 350.0 & $26.00 \mathrm{c}$ & 59.37 & $20.80 \mathrm{~b}$ & 69.41 \\
\hline Copper oxychloride $50 \mathrm{WP}$ & 300.0 & $37.00 \mathrm{~b}$ & 42.18 & $21.00 \mathrm{~b}$ & 69.11 \\
\hline Control & $(-)$ & $64.00 \mathrm{a}$ & - & $68.00 \mathrm{a}$ & - \\
\hline $\operatorname{LSD}(\mathrm{P}=0.05)$ & & 2.58 & - & 2.17 & - \\
\hline
\end{tabular}

*Reduction (\%) = Untreated seedlings - Treated seedlings/ Untreated seedlings $\mathrm{x} 100$

Note. Figures followed by the same letter within a column were not significantly different according to the LSD (least significant difference) test at $\mathrm{P}<0.05$

\section{DISCUSSION}

Mango (Mangifera indica L.) is one of the most important fruit crops grown in tropical and subtropical lowlands throughout the world. It is also a fact that Pakistani mangoes are considered far superior because of its excellent flavour and delicious taste. However, mango is attacked by a number of diseases (Pernenzy and Simone, 2000) and the malformation is amongst the important one. Currently, malformation is the threatening disease and occurs wherever mango grown in Pakistan (Ahmad et al., 2002). For the last many years research workers have been involved to study various aspects of mango malformation disease (MMD). There are also several lines of reports available in the literature regarding the specific cause of this disease. Numerous fungi have been reported associated with MMD and possibly the causal agents of the disease. Freeman et al., (2000) reported that Fusarium subglutinas (Gibberella fujikuroi) has been associated with mango floral and vegetative malformation. Iqbal et al., (2006) isolated four fungi viz. F. mangiferae, F. pallidoroseum, F. oxysporum and Alternaria alternata from malformed mango parts. Khaskheli et al., (2008b) isolated and identified Fusarium nivale (Fr.) Ces., as first record in Pakistan and also the first report of its association with mango malformation in Sindh, Pakistan.

However, the study regarding the management of MMD is not well documented. In current study, five different fungicides were tested in vitro and in vivo to see their effect on growth of $F$. nivale and disease development. Thiophanate methyl and FosetylAluminium at their low and high doses completely inhibited mycelial growth of F. nivale. Mycelial growth of the fungus was also reduced at low dose of
Metalaxyl+Mancozeb. Mancozeb was found to be less effective in reducing mycelial growth of the fungus as compared to Metalaxyl+Mancozeb. Similarly, Copper oxychloride was also found least effective against $F$. nivale at low dose and medium dose, respectively. When these fungicides tested on Fusarium nivale inoculated seedlings for diseases development, varied responses of fungicides were observed. Thiophanate methyl and Fosetyl- Aluminium reduced the infection of $F$. nivale in Desi, Almas and Dusheri varieties after first spray, with highest reduction percent in malformation over untreated control. Metalaxyl+Mancozeb and Mancozeb also reduced the infection as compared to Copper oxychloride, with decrease in intensity. Thiophanate methyl and Fosetyl- Aluminium after second spray completely reduced infection of the fungus with $100.0 \%$ decrease in intensity of the disease as compared to Metalaxyl+Mancozeb, Mancozeb and Copper oxychloride over untreated control on all tested seedlings of Desi, Almas and Dusheri varieties. Some other reports are also inconsistence with the current study to reduce the intensity MMD through different chemicals as well as with physical measures; however, their reported causal agents are different from the current tested fungi. Hafeez-ur-Rehamn et al. (1989) used Benlate and certain biological antagonists separately and as well as in combination. Benlate in both cases gave better result in reducing malformation intensity. Kumar et al., (1995) found that mangiferin, a metabolite of mango caused changes in various isolates of Fusarium moniliforme (Gibberlea fujikuroi).

It is suggested based on the current findings that Thiophanate methyl and Fosetyl- Aluminiumare the most effective fungicides against $F$. nivale, the causal 
agent of MMD in Sindh, Pakistan. These fungicides could be used for preventive as well as curative control of F. nivale and other species of Fusarium.

\section{REFERENCES}

Ahmad, F., I. A. Hafiz, A. A. Isi, S. Ahmed and M. Khan. 2002. Mango varietal susceptibility to malformation and its control. Asian J. Plt. Sci. 1(2): 158-159

Akhtar, K. P., I. A. Khan, M. J. Jaskani, M. Asif and M. A. Khan. 1999. Isolation and characterization of Fusarium moniliforme var. subglutinans, and Gibberella fujikuroi var. subglutinans from malformed mango. Sultan Qaboos Uni. J. Sci. Res. Agri. Sc. 42:19-25.

Analytical Software. 2005. Statistix 8.1, Tallahassee, FL.

Britz, H., E. T. Steenkamp, T. A. Coutinho, B. D. Wingfield, W. F. Marasas and M. J. Wingfield. 2002. Two new species of Fusarium Section Liseola associated with mango malformation. Mycologia. 94(4): 722730.

Freeman, S., M. Manimon and Y. Pinkas. 2000. Etiology of mango malformation disease using GUS transformants of Fusarium subglutinans. Acta Hort. 509: 751-758.

Hafeez, U.R., M.A. Khan, K. M. Khokhar, A. H. Shah and M. Khan. 1989. Effect of Benlate spray, biological antagonistis and time of deblossoming on malformation of mango inflorescence. Pak. J. Agric. Res. 19: 60-65.

Iqbal, Z, A. A. Dasti and A. Saleem. 2006. Role of Fusarium mangiferae in causation of mango malformation disease. J. Res. Sci. 17 (1): 9-14.

Iqbal, Z., N. Akhtar, M. U. Ghazanfar, S. M. Shehzad, S. Ahmad, M. Asif, M. Yasin, M. A. Pervez, A. A. Dasti and A. Saleem. 2011. Management of mango malformation through physical alteration and chemical spray. Afr. J. Agric. Res. 67: 1897-1901.

Khaskheli, M. I., M. A. Pathan, M. M. Jiskani, K. H. Wagan and S. P. Goswami. 2008a. Survey, Intensity and Varietal response of Mango Malformation Disease MMD in different Mango Orchards of Sindh, Pakistan. Pak. J. Agri., Agril., Engg., Vet. Sci. 24(1):53-56
Khaskheli, M.I., M.A. Pathan, M.M. Jiskani, K.H. Wagan, M.H. Soomro and G.B. Poussio. 2008b. First Record of Fusarium nivale Fr. Ces. associated with Mango Malformation Disease MMD in Pakistan. Pak. J. Bot. 40(6) 2641-2644.

Kumar, J., U. S. Singh and S. P. Beniwal. 1993. Mango malformation: One hundred years of research. Annu. Rev. Phytopathol. 31: 217-232.

Kumar, P., D. K. Chakrabarti, M. K. Dasgupta, D. C. Ghosh, D. Dasgupta, D. K. Majumdar, G. N. Chattopadhyay, P. K. Ganguli, P. S. Munsi and D. Bhattacharya.1995. Mango malformation: effect of mangiferin on morphology and parasitism in Fusarium moniliforme. Proc. Natl. Symp. on sustainable in sub-humid zone, March 3-5, 348-352.

Lonsdale, J. H. and J. M. Kotze. 1993. Chemical control of mango blossom disease and the effect on fruit set and yield. Plant Dis. 77:558-562.

Noriega-canto, D. H., D. Telliz, G. Mora-Aguilera, J. Rodriguez-Alcazar, E. Zavaleta-Mejfa, G. OteroCollinas and C.L. Campell.1999. Epidemiology of mango malformation in Guerrero, Mexico, with traditional and integrated management. Plant Dis. 83: 223-228.

Pernezny, K. and G. W. Simone. 2000. Diseases of Mango Mangifera indica L. In: Common names of plant diseases. Am. Phytopathol. Soc. St. Paul, MN.

Ploetz, R.C. 2001. Malformation: A unique and important disease of mango, Mangrfera indica L. In: Fusarium: Paul E. Nelson Memorial Symposium. B. A. Summerell, J. F. Leslie, D. Backhouse and W. L. Bryden, eds. The Am. Phytopathol. Soc. St. Paul, MN. 233-247

Ploetz, R. C., Q. I. Zheng, A. Vazguez and M. A. Abdel Sattar. 2002. Current status and impact of mango malformation in Egypt. Int. J. Pest Management. 48: 279-285.

Tahir, F. M., M. Ibrahim and K. Hamid. 2003. Effect of drought stress on vegetative and reproductive growth behavior of mango Mangifera indica L. Asian J. Plant Sci. 2(1): 116-118.

Towsend, G. R. and J. W. Henerberger. 1973. Methods for estimating losses caused by disease in fungicide experiments. Pl. Dis. Rept. 27:340-343. 